\title{
Pamiętniki żołnierzy uczestniczących w działaniach wojennych jako przykład materiałów uzupełniających wywiady biograficzne
}

DOI: 10.19195/2083-7763.7.4

Z perspektywy metodologicznej interesujące byłoby znalezienie takiego narzędzia badawczego, które umożliwi nadawanie sensu światu badanych przez sytuowanie ich doświadczeń w szerszym kontekście historycznym, politycznym i społecznym. Wiąże się z tym problem odnalezienia zasady, dzięki której badacz może usytuować i konstruować siebie jako zaangażowany w etyczne badania socjologiczne etyczny podmiot. Istotną rolę mogą w tym odgrywać dokumenty osobiste, takie jak choćby pamiętniki. Skłania to do refleksji, czy badacz, wykorzystując metodę wywiadów biograficznych, może je dopełnić analizami na podstawie różnego rodzaju zapisów autobiograficznych. Wywiady biograficzne (zgodne z metodologią biografistyczną zaproponowaną przez Fritza Schützego) przeprowadzono z żołnierzami oraz z byłymi żołnierzami, uczestnikami operacji wojskowych poza granicami kraju - w Iraku i Afganistanie. Osoby, z którymi rozmawiano, zostały poszkodowane (straciły zdrowie, sprawność fizyczną bądź psychiczną) na skutek działań wojennych podczas wspomnianych operacji wojskowych. W trakcie realizacji i po badaniach wyłoniły się pewne nieprzewidziane problemy. W ich konsekwencji konieczne było spojrzenie na badaną problematykę w nowy sposób. Chodzi o te ważne zagadnienia, często pojawiające się w badaniach poruszających kwestie traumatycznych przeżyć, a mianowicie: etyczność badań, rola badacza w tego rodzaju badaniach oraz obawa przed banalizacją, trywializacją badań. Ze względu na tematykę i drażliwość problemu badań od samego początku kładziono nacisk na to, aby miały one charakter refleksyjny. Istotne jest nie tylko opisanie społecznego konstytuowania się zbiorowości weteranów wojskowych, lecz także poznanie uwikłania badacza w realizowane przez niego 
badania. Tekst jest też próbą zastosowania metodologii właściwej dotychczas badaniom nad cywilnym doświadczeniem biograficznym do zbadania i opisu doświadczenia żołnierskiego, będącego dotychczas na ogół opisywanwym z perspektywy historycznej.

Zrealizowanie trzydziestu wywiadów wykazało, że o ile wywiady biograficzne są ciekawą metodą badawczą pozwalającą odkryć trajektorię cierpienia, w jaką „wpadli” weterani na skutek uczestnictwa w działaniach wojennych, o tyle nie pozwalają one dotrzeć do tego, co przez charakter wydarzeń, w których uczestniczyli, czyni doświadczenia weteranów wyjątkowymi, a które to doświadczenia są niezrozumiałe dla reszty społeczeństwa. Brak wspólnoty doświadczeń z osobami badanymi, obawa przed trywializacją badanego problemu oraz chęć odrzucenia patologizacji i egzotyzacji weteranów jako „innych” i tym samym odejście od zniewalającego nadzoru protekcjonalnego spojrzenia na badaną grupę, charakterystycznego dla większości społeczeństwa, zbliżającego się powoli do granicy wyznaczającego kryterium szacunku, otworzyło furtkę metodologiczną do zainteresowania się badaniami pamiętnikarskimi, albowiem pamiętniki pisane z „potrzeby serca" ${ }^{\prime}$, jako szczególnego rodzaju dokumenty osobiste, mogą stanowić uzupełnienie realizowanych badań lub być materiałem ilustrującym projekcje stanów umysłu żołnierzy uwikłanych w działania wojenne i readaptację po powrocie do codzienności domowej. Waga takich dokumentów jest istotna także dlatego, że jest to materiał wolny od wpływu sytuacji badawczej oraz daje możliwość dokonania wglądu w refleksyjną świadomość i indywidualną sferę wiedzy piszącego, a która ze względu na traumatyczność doświadczeń nie zawsze zostaje ujawniona w czasie wywiadu biograficznego. Fenomen pamiętników pisanych przez żołnierzy polega na tym, że obojętnie w jakie działania wojenne zostali oni uwikłani (I wojna światowa, II wojna światowa, wojny: w Wietnamie, na Falklandach, Zatoce Perskiej, Iraku, etc.) trzy zagadnienia oraz ich opis wydają się być uniwersalne: 1. stresogenność działań wojennych i ich wpływ na psychikę oraz biografię żołnierzy; 2. trudności związane z readaptacją żołnierzy do codzienności po powrocie do domu, co nierzadko jest kolejnym czynnikiem traumatyzującym, gdyż świat, za którym tęsknili, już nie wydaje się ich światem; 3. brak zrozumienia i wsparcia ze strony społeczeństwa i w konsekwencji marginalizacja żołnierzy.

W tym miejscu można zaznaczyć, że w działaniach wojennych widać problem natury kulturowej, a nie militarnej czy też politycznej. Tym samym należy traktować zachowanie żołnierzy w czasie różnych działań wojennych bardziej jako dane służące ich zrozumieniu niż rozumienie to utrudniające. W każdej

1 Pamiętniki pisane z „potrzeby serca” należy odróżnić od tych pisanych w celach konkursowych. Najprawdopodobniej konkurs uruchamia w autorze intencje innego rodzaju niż te, które przyświecają autorowi spontanicznie dokonującemu zapisu własnych przeżyć, niejako „do szuflady”. Przekładać się to może na strategię analizy, w której badacz porusza się w tych wymiarach tekstu, które nie odnoszą się do tytułu konkursu. Bada zatem tematy, które pojawiły się mimochodem i jakby przy okazji (Doliński 2015, s. 229-230). 
tradycji kulturowej istnieją ustalone zasady prowadzenia wojen, i niektóre z nich są wspólne dla wszystkich narodów Zachodu mimo dzielących je różnic: wypowiadanie wojny totalnej, pewne gwarancje na wypadek lokalnej klęski, reguły traktowania jeńców wojennych. Właśnie dlatego dadzą się one przewidzieć, że narody Zachodu mają wielką wspólną tradycję kulturową, która obejmuje takie zachowania w czasie działań wojennych. To, w jaki sposób postępujemy zgodnie $\mathrm{z}$ regułami prowadzenia działań wojennych, dostarcza danych na temat naszego światopoglądu, rozumienia kondycji człowieka oraz doświadczania sytuacji traumatycznej. Analiza poszczególnych narracji pozwala dociec istoty tego doświadczenia - ludzkiego, powszechnego, lecz także bardzo zindywidualizowanego $\mathrm{w}$ formie i intensywności przeżyć. Nie można spotkać identycznych trajektorii losu, ale doświadczenia związane z uczestnictwem w działaniach wojennych można potraktować jako wspólne doświadczenie biograficzne bez względu na kontekst militarny czy też polityczny tychże wydarzeń.

Zachodnia socjologia wojska, zwłaszcza amerykańska i brytyjska, często wykorzystuje metodę pamiętnikarską $\mathrm{w}$ celach: diagnostycznych (diagnozowanie problemów, z jakimi muszą zmierzyć się żołnierze powracający do domu z działań wojennych oraz jakie to stanowi wyzwanie dla ich rodzin); terapeutycznych (dla żołnierzy i ich rodzin) oraz popularyzatorskich, w których pamiętniki traktowane są jako świadectwo szczególnego rodzaju doświadczenia, obcego reszcie społeczeństwa i pozwalającego zrozumieć/zdefiniować, czym jest wojna, a także jaka jest jej natura oraz wpływ na życie żołnierzy. Ten ostatni cel jest w badaniach pamiętnikarskich o tyle istotny, że pozwala weteranom wyjść z cienia, przestać być człowiekiem marginalnym i przez swe doświadczenie obcym w społeczeństwie, a społeczeństwu zrozumieć tę specyficzną grupę społeczną. W Polsce metoda pamiętnikarska jest wykorzystywana przede wszystkim w procesie leczenia jako jedna $\mathrm{z}$ wielu metod terapeutycznych, pozwalających żołnierzom przepracować traumatyczne doświadczenia. Nieczęsto wykorzystuje się w Polsce pamiętniki do tych celów. Mimo że wspomnień byłych żołnierzy, weteranów działań wojennych (zwłaszcza II wojny światowej) jest dość dużo, to przede wszystkim koncentrują się one na opisywaniu m.in. bohaterstwa, często są też bezkrytyczne bądź pokazują działania wojenne jaką niezłą życiową przygodę. Natomiast rzadko opisują konsekwencje tych doświadczeń dla codziennego życie ich autorów. Tymczasem poza granicami Polski materiał pamiętnikarski jest bardzo zróżnicowany, co pozwala podzielić go na: 1. pamiętniki-blogi (pisane na bieżące w czasie działań wojennych, następnie wydane $\mathrm{w}$ formie książkowej); 2. pamiętniki żołnierzy uczestniczących w działaniach wojennych (napisane po powrocie do domu, charakteryzujące się niskim poziomem zinstytucjonalizowania pamięci, podobnie zresztą jak pamiętniki-blogi); 3. pamiętniki osób, które towarzyszyły żołnierzom podczas działań wojennych (np. dziennikarzy, lekarzy, duchownych); 4. pamiętniki wojskowe (pisane przez przedstawicieli instytucji wojskowych - armii), reprezentujące poziom instytucji należących do systemu władzy administracyjnej, 
a więc posiadające najszersze pole oddziaływania, poziom państwowej polityki pamięci; 5. zbeletryzowane pamiętniki; 6. pamiętniki pisane przez rodziny żołnierzy.

Należy jednak zaznaczyć, że do tej pory, zarówno w Polsce, jak i za granicą (Wielka Brytania, Stany Zjednoczone i pozostałe państwa NATO), nie zostały ogłoszone konkursy pamiętnikarskie adresowane do żołnierzy lub byłych żołnierzy, aczkolwiek materiał (głównie wywiady narracyjny) dotyczący ich doświadczeń biograficznych wynikających z zaangażowania $\mathrm{w}$ działania wojenne jest bogaty, gromadzony przez organizacje pomagające weteranom lub przez badaczy zajmujących się tą problematyką. Grupa badaczy na czele z prof. Rachel Woodward (Military Research at Newcastle University) przez ponad pięć lat zajmowała się analizą pamiętników wydanych w Wielkiej Brytanii na przestrzeni ostatnich 20 lat (por. Woodward 2007, 2008, 2012). Autorami tych pamiętników, opublikowanych w różnych wydawnictwach, byli żołnierze (kobiety i mężczyźni) biorący udział w działaniach wojennych (to była jedyna wspólna cech wszystkich autorów), służący w różnych rodzajach wojsk i o różnych dystynkcjach. Wspomniani badacze w swoich publikacjach nie tylko pokazali, że żołnierze w ogóle piszą o swoich doświadczeniach, lecz także zwrócili uwagę, że to, co i jak piszą, podlega autocenzurze, a publikowany materiał - mechanizmom cenzury wojskowej. Pamiętniki pisane przez żołnierzy (pamiętniki żołnierzy i pamiętniki wojskowe), opublikowane jako autobiograficzne refleksje tych, którzy uczestniczyli w działaniach wojskowych, mogą być (celowo lub też nie) wykorzystywane jako mechanizm do konstruowania poprawnej politycznie wizji działań wojennych i zaangażowanych w nich żołnierzy. To zdecydowanie ogranicza ich użyteczność, ponieważ przedstawiają perspektywę silnie zinstytucjonalizowaną, zestandaryzowaną. To konstruowanie poprawnej politycznie wizji nie dotyczy tylko treści zawartej w książce, lecz także widoczne jest w jej formie (np. stylistyce okładki). Bardzo często można na przykład zauważyć nieadekwatność okładki do treści zawartej w książce, co niewątpliwie warte jest osobnej analizy, gdyż może ona pokazać, jak instytucja wpływa na piszącą jednostkę i konstruuje jej narrację (czego jednostka niekoniecznie musi być świadoma), ucieleśnia się w niej.

Wiąże się to $\mathrm{z}$ problemem przemilczeń $\mathrm{w}$ narracjach biograficznych oraz strategii unikania opowiadania o pewnych wydarzeniach. Istnieje bowiem nieusuwalna dialektyczność między dwoma poziomami pamięci, oficjalną (instytucjonalną) oraz indywidualną. W tak rozumianej narracji biograficznej kluczowa w problematyce przemilczeń wydaje się dychotomia pamięć-niepamięć. Pojęcie niepamięci, zaproponowane przez Paula Ricoeura (2006), miałoby dopełniać obrazu samej pamięci, rozumianej zawsze jako forma odpowiedzi na niepamięć. W tym sensie przypomnienie sobie pewnych treści byłoby nade wszystko wydobyciem ich z niepamięci (Ricoeur 2006, s. 83), a dialektyczny stosunek obu tych 
pojęć zakładałby nieustanny proces włączania i wykluczania pewnych elementów z obszaru pamięci, czy to zbiorowej, czy indywidualnej.

W ramach obszaru niepamięci zaproponowane przez Ricoeura rozróżnienie na zapominanie bierne (unikanie konfrontacji z przeszłością) i aktywne (zmierzające do selekcji pamięci) w przybliżeniu odpowiadałoby podziałowi wypracowanemu na gruncie socjologii biograficznej przez Fritza Schützego. Otóż Schütze wykorzystuje synonimiczny do przemilczenia termin „przesłonięcie”, który rozumie jako "całkowite lub częściowe pominięcia lub luki pojawiające się w narracji, a dotyczące istotnych doświadczeń biograficznych" (Rokuszewska-Pawełek 2002, s. 55). Następnie wyróżnia przesłonięcie niezamierzone (ówczesne) - związane $\mathrm{z}$ doświadczeniem w przeszłości jakiegoś cierpienia, skutkującego wypieraniem określonych wspomnień, oraz przesłonięcie zamierzone (teraźniejsze) - rodzaj celowego zamaskowania określonych doświadczeń ze względu na ich problematyczność z punktu widzenia bieżącej tożsamości osobistej lub społecznej narratora (ibidem). W analizowanej narracji ten drugi rodzaj ma szczególne znaczenie.

Aby móc odpowiedzieć na pytanie o słuszność wykorzystania pamiętników jako dokumentów uzupełniających, zrealizowane wywiady biograficzne skupiają się na pamiętnikach pisanych przez żołnierzy uczestniczących w działaniach wojennych. Z powodu niedostatecznej ilości wspomnianych materiałów w języku polskim oraz ze względu na uniwersalność opisywanych w nich problemów postanowiono przedstawić użyteczność pamiętników jako metody uzupełniającej badania biograficzne na przykładzie pamiętnika Guya Sajrego Zapomniany żotnierz (2013). Wybór tego pamiętnika był celowy, ponieważ przedstawia on wpływ brutalności działań wojennych na biografię żołnierzy i jest dobrą ilustracją refleksyjnej świadomości piszącego. Jest to źródło ukazujące osobowość pamiętnikarza w związku z jego otoczeniem, wzorem postaw i akceptowanych wartości oraz relacji z społeczeństwem. Jak ciężkie do przepracowania dla Guya Sajrego były doświadczenia żołnierskie, może świadczyć to, że dopiero czterdzieści lat po II wojnie światowej był w stanie je przedstawić w formie pisemnej. Sam autor opisał to w następujący sposób:

Walczyłem tylko trzy lata i aż trzy lata. Wojna wycisnęła na mojej psychice niezatarte piętno. Tak
trwałe, że nie zdołałem znaleźć dla siebie miejsca wormalnym życiu, ponieważ nie opuszczał
mnie dręczący i ponury lęk. Tak mocne, że wyzwoliło to we mnie pragnienie przelania na pa-
pier wojennych przeżyć. Ale byłem gotowy to zrobić dopiero czterdzieści lat po jej zakończeniu
(Sajri 2013, s. 11).

Próba zmierzenia się z takim materiałem oraz potraktowanie go jako uzupełnienie badań biograficznych jest o tyle istotne, że może stanowić podstawę do promowania w Polsce badań pamiętnikarskich służących do realizacji wspomnianych celów diagnostycznych, terapeutycznych i popularyzatorskich, które mogą pomóc nie tylko samym autorom, lecz także osobom na co dzień mającym kontakt $\mathrm{z}$ weteranami w życiu zawodowym lub prywatnym (socjologom, psychologom, 
pracownikom socjalnym, innym żołnierzom, wojsku). W pamiętnikach, które analizowano, działania wojenne fundamentalnie zmieniły mentalność oraz tożsamość żołnierzy. Żołnierze doświadczają totalnego fizycznego, psychicznego i emocjonalnego załamania skutkującego zmianą wspomnianej mentalności i tożsamości. Po opuszczeniu armii oraz terenu działań wojennych napotykają wiele problemów wynikających z konieczności zaadaptowania się do nowych/ starych warunków (por. Schutz 2012, s. 203-213). Muszą na nowo przystosować się do życia w cywilu. Opuszczając wojsko, opuszczają też w pewnym sensie „rodzinę"/,wspólnotę doświadczen". To jest czas, który jest determinowany nie tylko doświadczeniami wojennymi, lecz przede wszystkim koniecznością ponownego stania się cywilem oraz niemożnością dostosowania się do życia. Skutkuje to lub może skutkować zachowaniami agresywnymi i autoagresywnymi, próbami samobójczymi, depresją, uzależnieniem, problemem z utrzymaniem pracy, rozpadem rodziny.

Z wstępnej analizy pamiętników wyłaniają się dwa typy wspomnień, które pojawiają się także $\mathrm{w}$ zrealizowanych wywiadach biograficznych. Typami tymi są wspomnienia: 1. natrętne (implicite) i 2. przepracowane (explicite).

Wspomnienia natrętne są trudno wyrażalne, nieświadome, niekontrolowane, powiązane $\mathrm{z}$ bardzo silnymi emocjami i pobudzające do agresywnych oraz nieprzewidzianych działań. Są też bardzo mocno związane z traumatycznymi i uśpionymi (latentnymi) przeżyciami. Rozmówcy opisywali, że moment pojawienia się tych wspomnień jest nie do przewidzenia. Zapach, dźwięk dzwonka, jakiekolwiek codzienne wydarzenie może przyczynić się do ich pojawienia. Konsekwencją jest nagła zmiana nastroju i zachowania. Niektórzy porównywali to do zmiany, jaką przechodził doktor Jekyll zamieniający się w Pana Hydea. Dobrze opisują to słowa zacytowane przez córkę jednego z moich rozmówców: „Mamo! On znów staje się Nim!!!” Podobny rodzaj wspomnień odnaleziono także w pamiętnikach Guya Sarjego, który opisywał je jako coś „od czego nie da się uciec, bo im bardziej starasz się uciec, tym większe męki przeżywasz; im bardziej starasz się uciec, tym szybciej one ciebie gonią" (Sajri 2013, s. 30). Z wypowiedzi rozmówców oraz z pamiętników można dowiedzieć się, że z tymi natrętnymi myślami wiążą się także koszmary senne (przeżywanie na nowo doświadczeń wojennych), poczucie winy (odnoszące się tylko do poległych lub rannych kolegów, rzadko do cywili) oraz okrucieństwo, którego byli świadkami (lub którego doświadczyli oni sami lub ich koledzy). Przykładem okrucieństwa powracającego natrętnie jako wspomnienie jest opowieść jednego z rozmówców, który musiał sprowadzić do bazy z irackiej wioski zwłoki swojego kolegi, którego głowa była przyszyta do tułowia psa. W pamiętnikach Guya Sarjiego wspomnienia okrucieństwa są wielokrotnie opisywane. Jedno z nich dotyczy wydarzenia, kiedy dowódca Guya Sajrego zabił jego najlepszego przyjaciela tylko za to, że ten popłakał się na widok dzieci, które płakały nad zwłokami swojej matki (została ona zabita przez rzeczonego dowódcę) (Sajri 2013, s. 245). 
Drugim typem wspomnień są wspomnienia przepracowane (expliciete), z którymi rozmówcy potrafią już sobie radzić. Są one powiązane z silnymi, kontrolowanymi emocjami (agresja, smutek), ale już nie tak gwałtownymi i wpływającymi na zachowanie jak opisane powyżej. Te wspomnienia umożliwiają retrospektywne spojrzenie na własne doświadczenia oraz dostrzeżenie wpływu, jakie one mają na osobowość i życie codzienne. Rozmówcy często podkreślali, że jak już nauczyli się kontrolować swoje emocje wywołane przez natrętne wspomnienia oraz przepracowali traumatyczne doświadczenia, zauważyli, że im bardziej są w stanie je zaakceptować, tym częściej one do nich wracają i stają się, jak stwierdził to jeden z rozmówców, „prywatną i intymną legendą życia”. Bardzo często te wspomnienia są koloryzowane. Na takie przepracowanie wspomnień w swoich pamiętnikach wskazywał także Guy Sajri, który „pamiętał wszystko sprzed czterdziestu lat; powracają do mnie szczegóły, na które, gdy walczyłem, nie zwracałem uwagi lub bardzo szybko o nich zapominałem" (Sajri 2013, s. 149).

Zarówno badani rozmówcy, jak i Guy Sajri wskazywali także w swoich pamiętnikach na kilka sposobów radzenia sobie z traumatycznymi doświadczeniami w czasie działań i po działaniach wojennych. Są to: fatalizm (wiara, że nie ma innego wyjścia z danej sytuacji), unikanie myślenia o traumatycznych doświadczeniach, wiara w sprawiedliwość wojny, odnajdywanie się w kultywowaniu braterstwa broni, aktywność fizyczna oraz jakakolwiek forma kontaktu z bliskimi (listy, internet, kontakt telefoniczny).

Interesujące jest także to, że zarówno badani rozmówcy, jak i Guy Sajri swoje doświadczenia przyrównywali do czterostopniowego czyśćca. Pierwszy stopień to wstyd i nieradzenie sobie z pojawiającymi się gwałtownie i niekontrolowanie emocjami. Drugim jest cierpienie związane z próbą zrozumienia doświadczeń i własnych wspomnień. Trzeci to uzyskanie wiedzy o nowym sobie i nabycie umiejętności kontrolowania emocji. Ostatnim, czwartym, jest afirmacją, akceptacją nowego siebie.

Pamiętniki żołnierzy trzymają w napięciu. Jest to kwestia narracji, czekania na przełom, odbicia się od dna oraz porzucenia traumatycznych doświadczeń. Częściej jednak chodzi o przełamanie bariery czyjejś intymności. Pamiętnik to rodzaj spowiedzi, a wydany zmienia się w coś na kształt rozmowy. Rozmowy przyciszonym głosem, bo traktującej o rzeczach bolesnych, intymnych, wstydliwych, zamkniętych w czterech ścianach domów.

Prowadzenie autonarracji jest sposobem na uporządkowanie świata i jasne określenie swojego w nim miejsca. Pamiętnik jako rodzaj autorefleksji ma charakter terapeutyczny. Jeśli proces wchodzenia w głąb siebie i własnych przeżyć, osiąganie stanu szczerości z samym sobą połączymy z opisem, który ma służyć innym jako wiedza o stanie ducha - pamiętnik może stać się równią pochyłą, po której piszący zstępuje, uświadamiając sobie własne położenie jeszcze dobitniej, obiektywizując je i absolutyzując. Ważnym wymiarem pamiętników jest możliwość oddania głosu żołnierzom, przyznanie im prawa do mówienia we własnym imieniu. 
I w tym sensie pamiętniki są niewątpliwie sposobem, choćby cząstkowym, na odzyskanie przez ich autorów godności oraz uzyskanie społecznego sprawstwa.

Pisanie pamiętników przez żołnierzy wymagałoby jednak zmiany uznawanego za oficjalny wizerunku żołnierzy uczestniczących w działaniach wojennych, to znaczy otworzenia się na ich indywidualny, nie zaś zinstytucjonalizowany i oficjalny wizerunek. Tego właśnie poszukuje się w pamiętnikach i dlatego postanowiłam wykorzystać technikę pamiętnikarską jako uzupełnienie materiału biograficznego uzyskanego dzięki zrealizowanym wywiadom biograficznym. To także dążenie do nasycenia teoretycznego zebranych danych i tym samym dążenie do poszukiwania uniwersalności doświadczeń osób uwikłanych w działania wojenne, jako aktywnych aktorów tych wydarzeń. Dzięki takim poszukiwaniom możliwe będzie pokazanie, jak bardzo doświadczenia biograficzne, zwłaszcza takie jak doświadczenia żołnierzy biorących udział w działaniach wojennych, są uwikłane w kontekst kulturowy i polityczny. A ten kontekst każe nam uważać każdą wojnę, każde doświadczenie wojenne jako niepowtarzalne i zależne tylko i wyłącznie od tego konkretnego wydarzenia.

$\mathrm{Z}$ materiałów uzyskanych dzięki wywiadom biograficznym wyłoniły się dwa typy doświadczeń biograficznych, które można powiązać z różnym stopniem zaangażowania $\mathrm{w}$ przepracowywanie doświadczenia biograficznego. Wstępnie te typy nazwano: 1 . bohater oraz 2 . samochwała. Obydwa typy doświadczeń charakteryzują się tendencją do unikania konfrontacji z przeszłością oraz selekcyjną pamięcią. Bohaterowie przedstawiają swoje doświadczenie i siebie w sposób patetyczny, z pominięciem negatywnych czynników, które mogłyby zaburzyć portret bohatera walczącego w dobrej sprawie. Ten typ zbliżony jest do wszelkich narracji opisujących doświadczenie polskich żołnierzy, zwłaszcza powstańców warszawskich, walczących w czasie II wojny światowej. Typ samochwały charakteryzuje się tendencją do opisywania doświadczenia jako swoistego rodzaju rytuału przejścia/inicjacji z fazy chłopca w fazę mężczyzny. Aktualnie poszukuje się w pamiętnikach przykładów opisujących właśnie taki typ doświadczeń żołnierskich i biograficznych. Szukając pamiętników żołnierzy i analizując je, cały czas mam jednak na uwadze, że tego, co badam, nigdy nie uda się w pełni opisać ani zrozumieć, co dobrze opisał bohater książki Remarque’a Na Zachodzie bez zmian (2014).

\footnotetext{
Jedyną osobą, która mnie o nic nie pyta, jest moja matka. Już z ojcem jest inaczej. Chciałby, abym mu opowiadał o froncie, życzenia jego wydają mi się wzruszająco głupie, nie mam już do niego właściwego stosunku. Chciałby stale słyszeć coś nowego. Rozumiem, nie wie, że coś takiego nie może być opowiedziane, rad bym uczynić mu zadość, ale niebezpiecznie jest dla mnie wyrażać te rzeczy w słowach, lękam się, czy nie rozrosną się gigantycznie, czy już można je będzie poskromić. Cóż by się z nami stało, gdybyśmy sobie uświadomili, co się dzieje na froncie. Nikt tego nigdy nie zrozumie (s. 119).
}

Podczas badań jakościowych należy dążyć do uzyskiwania takich materiałów badawczych, które pozwolą w pełni wyrazić się osobom badanym. To może być wywiad biograficzny, lecz także napisany własnoręcznie przez badanych pamiętnik. 
Badania biograficzne mogą w pewnym stopniu oddać i opisać to, co czuje i przeżywa rozmówca, ale nie do końca. Zawsze jest to jakaś forma konstrukcji/rekonstrukcji tego, co dostrzega badacz, nie zaś badany. W tej sytuacji najbardziej korzystne dla badanych jest pisanie/opisywanie (w jakiejkolwiek formie) swojej nowej sytuacji oraz siebie samych. Przede wszystkim dlatego, że czasem trudno jest (o)powiedzieć komuś cokolwiek o sobie, o swoich uczuciach, problemach, jeśli osoba, która słucha, nigdy nie doświadczyła tego, co osoba opowiadająca. Zdecydowanie lepiej i łatwiej (dla badanego) jest to napisać. I potraktować to jako świadectwo szczególnego rodzaju doświadczenia obcego badaczowi oraz reszcie społeczeństwa i pozwalającego zrozumieć/zdefiniować, czym jest badany problem, a także jaka jest jego natura i jak to wpływa na życie badanego. Jeśli zatem pewne doświadczenia trudno wypowiedzieć na głos, dobrać odpowiednie słowa do opisania takich, a nie innych przeżyć, to może dobrym rozwiązaniem jest pisanie pamiętników. Podjęcie zadania wyrażenia w piśmie tego, co jest niewypowiadalne na głos.

\section{Bibliografia}

Doliński W. (2015), Oblicza Ukrainy w pamiętnikach na konkurs „Polacy w Europie - Europa wśród Polaków”, [w:] Sąsiedztwa III RP - Ukraina. Zagadnienia społeczne, red. M. Dębicki, J. Makaro, Wrocław, s. 226-251.

Remarque E.M. (2014), Na Zachodzie bez zmian, przeł. R. Wojnarowski, Poznań.

Ricoeur P. (2006), Pamięć, historia, zapomnienie, przeł. J. Margański, Warszawa.

Rokuszewska-Pawełek A. (2002), Chaos i przymus. Trajektorie wojenne Polaków, Łódź.

Sajri G. (2013), Zapomniany żołnierz, przeł. J. Kortas, Gdańsk.

Schutz A. (2012), Powracający do domu, [w:] idem, O wielości światów. Szkice z socjologii fenomenologicznej, Kraków, s. 203-213.

Woodward R. (2012), Military memoirs and the reproduction of public narratives of war, ,Journal of War and Culture Studies" 5, s. 230-250.

Woodward R. (2007), Narratives of destruction and survival: writing and reading about life in urban war zones, „Theory and Event” 10, s. 310-330.

Woodward R. (2008), "Not for Queen and Country or any of that shit...": reflections on citizenship and military participation in contemporary British soldier narratives, [w:] War, Citizenship, Territory, red. E. Gilbert, London, s. 363-384.

\section{The soldiers' memoirs involved in the warfare as an example of additional materials in biographical research}

\section{Summary}

The aim of the article is an attempt to explore the role of personal documents in sociological research. I asked myself whether it makes sense to use those documents as an additional material describing the problems raised by people with whom I carry out biographical interviews. The interviews were conducted with soldiers and former soldiers, participants of military operations 
in Iraq and Afghanistan. During and after the interviews have emerged some problems, which I did not predict, and which surprised me and have prompted to look at my research in a new way. Those problems are related with important issues concerning: ethical research, the role of the researcher, its impact on research, as well as the fear of trivialization of research. I think that the memoirs, as a particular kind of personal documents, may complement my research or be a material illustrating states of mind of the soldiers involved in the war and their readaptation to the everyday life after returning a home. The validity of those documents is also significant because the material is free from the influence of research situations and gives the possibility to scrutinize the reflexive consciousness and individual sphere of writer's knowledge, which is not always be revealed during the biographical interview. 